Volume 4, Number 2, 2018

\title{
Method of Selecting the Speed of Jack Pump Driving Motor Based on Reservoir Flow Rate
}

\author{
Andriy Malyar*, Bohdan Kaluzhnyi, Roman Kvit \\ Lviv Polytechnic National University, 12 S. Bandera St., Lviv, 79013, Ukraine
}

Received: November 05, 2018. Revised: November 20, 2018. Accepted: December 07, 2018.

(C) 2018 Authors. Published by Lviv Polytechnic National University.

\begin{abstract}
The sucker-rod oil pumping unit productivity is influenced by lots of factors, including the operation mode of the jack pump electric drive system. Settings of the electric drive system affect the system's energy indicators, overhaul period and oil production volume. Therefore, an effective operation of oil production units is an important factor influencing the cost of the produced oil. The paper proposes a method of selecting the speed of the driving motor of the jack pump electric drive that allows balancing the sucker-rod oil pumping unit productivity and the reservoir flow rate. The difference between the pump productivity and that of the reservoir is taken as the electric drive system error. The method is based on the criterion of root-mean-square error minimum and takes into consideration the periodically variable nature of the load torque and inertia moment of the electric drive. It can be used to synthesize a control system for the jack pump electric drive for adjusting the operation of the sucker-rod oil pumping unit to different values of the oil inflow.
\end{abstract}

Keywords: sucker-rod oil pumping unit; flow rate; control system; root-mean-square error.

\section{Formulation of the research problem.}

The oil well production technology needs balancing in terms of the oil reservoir inflow rate and the rate of oil pumping by a sucker-rod pump, at least for a certain period of time. The sucker-rod oil pumping unit productivity depends on the pump strokes per minute and technical condition of the unit itself, which can deteriorate with time, thereby causing the reduction in productivity. The inflow rate, or reservoir productivity, is determined by the level of the oil filling the well and condition of the borehole zone of the reservoir. Under certain conditions of the well's operation, the oil level in it corresponds to the dynamic equilibrium between the inflow and pumping rates and is referred to as the dynamic level. Obviously, the best operation mode of the well is the mode in which the dynamic level is established at the level of the plunger pump working submergence [1], thereby ensuring the improvement of technical and economic indices of the sucker-rod oil pumping unit.

Nowadays in Ukraine, wells with sucker-rod pumps are operated mostly by non-regulated electric drives of jack pumps. In this situation, the balance between the rates of oil inflow into the well and its pumping from it is ensured by the periodic operation mode. In this mode, the jack pump runs for some time, pumping the oil from the well (the pumping period), and some time it is in the stand-by mode (the stand-by period). During the latter period, the oil that comes from the reservoir fills in the well and the oil level increases (the replenishment period).

A high efficiency of periodic operation can be achieved only subject to the development and application of advanced automated control systems for jack pump electric drives. Practice shows that the use of the frequencycontrolled electric drive is proposed for regulating the productivity of periodic wells [2-5]. This approach provides for changing the rate of oil pumping from the well, using an automated control system. In most cases, such systems

\footnotetext{
* Corresponding author. Email: andrii.v.maliar@lpnu.ua
}

This paper should be cited as: A. Malyar, B. Kaluzhnyi, R. Kvit. A method of selecting the speed of the jack pump driving motor based on the reservoir flow rate. Energy Eng. Control Syst., 2018, Vol. 4, No. 2 , pp. 87 - 92. https://doi.org/10.23939/jeecs2018.02.087 
operate on the basis of a preset algorithm with corresponding settings which are determined when exploring the well [2,5]. At that, for a specific jack pump drive one needs to adjust the control algorithm, as each well has its specificities. Therefore, the issue of developing a method of determining the driving motor speed, based on which the control system of the jack pump will ensure operation modes of the sucker-rod oil pumping unit adjusted to different values of oil inflow into the well, is of topical importance.

\section{Evaluation of the jack pump electric drive speed.}

Since the pumping rate for the stripper well, as a rule, exceeds that of oil inflow into it, this causes a reduction in the energy conversion efficiency of the oil pumping unit. To ensure the balance between the oil inflow and pumping rates, it is necessary to adjust the pump productivity so that the error $E$ would be equal to zero or approaching zero according to the formula [6]

$$
E=Q_{r e s}-Q_{p}=Q_{r e s}-1440 n_{c r} S D k_{p}=0,
$$

where 1440 is the number of minutes in a day; $Q_{r e s}, Q_{p}$ are theoretical and real daily production rate of the well; $n_{c r}$ is the number of swings of the jack pump (revolutions of the crank); $S$ is the plunger stroke length; $D$ is the plunger area; $k_{p}$ is the volume efficiency of the sucker-rod pump calculated as the ratio of the real volume efficiency to the theoretical one; in practice, this coefficient falls into the range 0.65-0.9.

Taking into account that the crank rotation speed is calculated as

$$
n_{c r}=\frac{30}{\pi} \frac{\omega_{m}}{k_{i}},
$$

where $k_{i}$ is the reduction gear ratio from the induction motor shaft to the crank rotation axis, $\omega_{m}$ is the speed of the driving motor shaft, the equation (1) can be written as

$$
E=Q_{\text {res }}-1440 S D k_{p} \frac{30}{\pi} \frac{\omega_{m}}{k_{i}}=0 .
$$

For the equation (2) to be satisfied, the control system of the jack pump electric drive must change the driving motor speed according to the change of the current productivity of the unit. For quality assessment of such a system, we will use the criterion in the form of the square error integral

$$
I=\int_{0}^{2 \pi} V d \alpha=\int_{0}^{2 \pi}\left(E^{2}+\gamma\left(\frac{d E}{d \alpha}\right)^{2}\right) d \alpha \rightarrow \min ,
$$

where $\gamma$ is a certain set constant.

If we take that the volume efficiency of the sucker-rod pump is a constant value, then

$$
\frac{d E}{d \alpha}=-1440 S D k_{p} \frac{30}{\pi k_{i}} \frac{d \omega_{m}}{d t}=-K \frac{d \omega_{m}}{d \alpha} .
$$

It is known [7] that if the mechanical time constant significantly exceeds the electromagnetic time constant, the transfer function of the driving induction motor powered from the frequency converter on the linear section of the speed-torque curve with respect to the speed setpoint adjuster signal will appear as

$$
W(p)=\frac{1}{T_{e} T_{m} p^{2}+T_{m} p+1},
$$

where $p=d / d t ; T_{e}$ is the electromagnetic time constant; $T_{m}$ is the mechanical time constant. 
Taking into account that on the period of swinging the inertia moment $J$ of the electric drive depends on the crank rotation angle $\alpha$, then, in our case, the mechanical time constant is also a function of the angle $\alpha$, i.e. $T_{m}(\alpha)=J(\alpha) / \beta$, where $\beta$ is the rigidity of the speed-torque curve on the linear section.

Using the mathematical model of the jack pump [8] and varying the angle $\alpha$ with a certain increment, we can calculate in advance the inertia moment $J(\alpha)$, its derivative and mechanical time constant $T_{m}(\alpha)$ on the period of the crank rotation and form the respective data arrays (Fig.1).

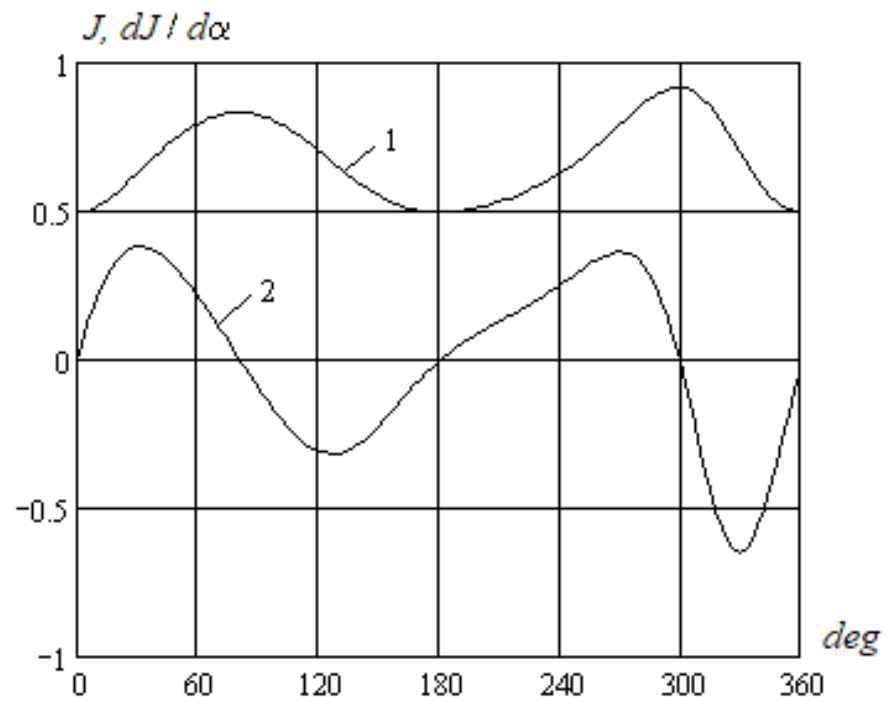

Fig.1. Inertia moment (1) and its derivative (2) vs. crank rotation angle.

Since the time coordinate $t$ is related to the angle coordinate $\alpha$ of the crank rotation according to $d t=k_{i} d \alpha / \omega_{m}$, the differential equation for the error $E$ will appear as

$$
T_{e} T_{m}(\alpha)\left(\frac{\omega_{m}}{k_{i}}\right)^{2} s^{2} E+T_{m}(\alpha) \frac{\omega_{m}}{k_{i}} s E+E=0,
$$

where $s=d / d \alpha$.

Let us make the following substitutions: $E=x_{1}, s E=x_{2}$. Then the equation (6) will transform into

$$
s x_{2}=-\frac{x_{1}+T_{m}(\alpha) \frac{\omega_{m}}{k_{i}} x_{2}}{T_{e} T_{m}(\alpha) \frac{\omega_{m}}{k_{i}}} .
$$

For the minimization of the criterion (3), we will use the auxiliary quadratic form

$$
Z=B_{1} x_{1}^{2}+2 B_{12} x_{1} x_{2}+B_{2} x_{2}^{2}
$$

related to the form $V$ according to

$$
\frac{d Z}{d \alpha}=-V
$$

Therefore, we have the positively definite form $V$, i.e. the function of coordinates $x_{j}$, which is positive for all real values of $x_{j}$. For $d V / d \alpha<0$, this form is known as a Lyapunov function [9-10]. In its turn, if $Z$ is a quadratic form positive for all values of $x_{j}$, and its derivative is negative, then $Z$ is also a Lyapunov function. 
The coefficients of the form (8) are unknown. It is shown in [10] that, having obtained the unknown coefficients, we will thereby obtain the expression for the integral (3). To this end, let us write the equation (9) as

$$
\frac{\partial Z}{\partial x_{1}} \frac{d x_{1}}{d \alpha}+\frac{\partial Z}{\partial x_{2}} \frac{d x_{2}}{d \alpha}=-V
$$

Taking into consideration the expression (7) and the above-made substitutions, the expression (10) will transform into

$$
\begin{aligned}
& 2\left(B_{1} x_{1}+B_{12} x_{2}\right) x_{2}+2\left(B_{12} x_{1}+B_{2} x_{2}\right)\left(-\frac{x_{1}+T_{m}(\alpha) \frac{\omega_{m}}{k_{i}} x_{2}}{T_{e} T_{m}(\alpha) \frac{\omega_{m}}{k_{i}}}\right)= \\
& =2 B_{1} x_{1} x_{2}+B_{12} x_{2}^{2}-2 B_{12} \frac{x_{1}^{2}}{T_{e} T_{m}(\alpha) \frac{\omega_{m}}{k_{i}}}-2 B_{12} \frac{x_{1} x_{2}}{T_{e}}-2 B_{2} \frac{x_{1} x_{2}}{T_{e} T_{m}(\alpha) \frac{\omega_{m}}{k_{i}}}-2 B_{2} \frac{x_{2}^{2}}{T_{e}}= \\
& =-x_{1}^{2}-\gamma x_{2}^{2} .
\end{aligned}
$$

In order to find the unknown coefficients, let us equate the expressions in front of $x_{1}^{2}, x_{1} x_{2}, x_{2}^{2}$ in the left and right parts of the equation (11) and solve the resulting system of equations. We obtain

$$
\begin{aligned}
& B_{1}=\frac{2 T_{m}^{2}(\alpha) \frac{\omega_{m}}{k_{i}}+T_{e} T_{m}(\alpha) \frac{\omega_{m}}{k_{i}}+2 \gamma}{4 T_{m}} ; \\
& B_{12}=\frac{T_{e} T_{m}(\alpha) \frac{\omega_{m}}{k_{i}}}{2} ; \\
& B_{2}=\frac{T_{e}^{2} T_{m}(\alpha) \frac{\omega_{m}}{k_{i}}}{4}+\frac{T_{e} \gamma}{2} .
\end{aligned}
$$

According to [8], after the change from the time coordinate to the angle coordinate, the expression for the integral (3) will appear as

$$
I=\int_{0}^{2 \pi} V d \alpha=B_{1}\left(x_{1}^{2}\right)_{0}+2 B_{12}\left(x_{1}\right)_{0}\left(x_{2}\right)_{0}+B_{2}\left(x_{2}^{2}\right)_{0},
$$

where $\left(x_{1}\right)_{0}=Q_{\text {res }}$,

$$
\left(x_{2}\right)_{0}=-K \frac{M_{m 0}-M_{l_{0}}-\frac{\omega_{m}^{2}}{2 k_{i}} \frac{d J(\alpha)}{d \alpha}}{J(\alpha) \frac{\omega_{m}}{k_{i}}} \text { are initial conditions; }
$$

$M_{m 0}$ is the initial motor torque;

$M_{l 0}$ is the initial load torque. 
Finally, the expression (13) for the integral evaluation will have the form

$$
\begin{aligned}
I & =\int_{0}^{2 \pi} V d a=\frac{2 T_{m}^{2}(\alpha) \frac{\omega_{m}}{k_{i}}+T_{e} T_{m}(\alpha) \frac{\omega_{m}}{k_{i}}+2 \gamma}{4 T_{m}} Q_{r e s}^{2}+ \\
& +T_{e} T_{m}(\alpha) \frac{\omega_{m}}{k_{i}} Q_{r e s}\left(-K \frac{M_{m}-M_{l}-\frac{\omega_{m}^{2}}{2 k_{i}} \frac{d J(\alpha)}{d \alpha}}{J(\alpha) \frac{\omega_{m}}{k_{i}}}\right)_{0}+ \\
& +\left(\frac{T_{e}^{2} T_{m}(\alpha) \frac{\omega_{m}}{k_{i}}}{4}+\frac{T_{e} \gamma}{2}\right)\left(-K \frac{M_{m}-M_{l}-\frac{\omega_{m}^{2}}{2 k_{i}} \frac{d J(\alpha)}{d \alpha}}{J(\alpha) \frac{\omega_{m}}{k_{i}}}\right)^{2} .
\end{aligned}
$$

Using (14), we can obtain the expression for the driving motor speed which ensures a minimum root-meansquare error. To this end, let us differentiate the expression (14) with respect to $\omega_{m}$. As a result, we obtain the function

$$
\begin{aligned}
f\left(\omega_{m}\right)= & \frac{Q_{r e s}^{2}\left(\frac{2 T_{m}{ }^{2}(\alpha)+T_{e} T_{m}(\alpha)}{k_{i}}\right)}{4 T_{m}(\alpha)}+\frac{K \cdot T_{e}^{2} \cdot T_{m}(\alpha)\left(M_{l}-M_{m}+\frac{d J(\alpha)}{d \alpha} \frac{\omega_{m}^{2}}{2 k_{i}}\right)^{2}}{4 J^{2}(\alpha) k_{i}}+ \\
& +\frac{\frac{d J(\alpha)}{d \alpha} K^{2} \omega_{m}\left(\frac{\gamma T_{e}}{2}+\frac{T_{e}^{2} T_{m}(\alpha) \omega_{m}}{4 k_{i}}\right)}{J^{2}(\alpha) k_{i}} \cdot \frac{\left(M_{l}-M_{m}+\frac{d J(\alpha)}{d \alpha} \frac{\omega_{m}^{2}}{2 k_{i}}\right)^{2}}{J^{2}(\alpha) k_{i}}+ \\
& +\frac{K \cdot Q_{r e s} \cdot T_{e} \cdot T_{m}(\alpha)\left(M_{l}-M_{m}+\frac{d J(\alpha)}{d \alpha} \frac{\omega_{m}^{2}}{2 k_{i}}\right)}{J(\alpha) k_{i}}+\frac{\frac{d J(\alpha)}{d \alpha} K \cdot Q_{r e s} \cdot T_{e} \cdot T_{m}(\alpha) \omega_{m}^{2}}{J(\alpha) k_{i}^{2}} .
\end{aligned}
$$

In order to find the extremum of the function $f\left(\omega_{m}\right)$, it is necessary to equate the expression (15) to zero and solve the obtained non-linear equation, using a numerical method. When solving the equation, it should be taken into account that the load torque created by the jack pump and therefore the motor torque are periodically variable (Fig.2). For obtaining periodic dependencies of the motor torque $M_{m}=M_{m}(\alpha)$, projection method described in [11] or experimentally recorded data can be used.

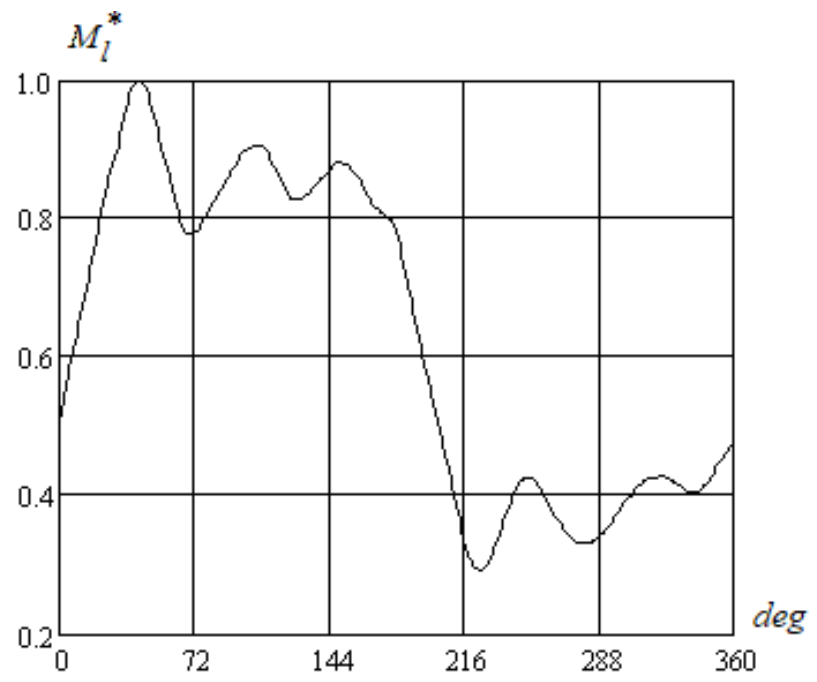

Fig. 2. Load torque per unit vs. crank rotation angle. 


\title{
3. Conclusion
}

The approach described above allows optimization of the jack pump electric drive operation, applying the proposed method. Therefore, we can obtain the motor speed variation law that will ensure effective operation of the sucker-rod oil pumping unit and balance between the oil inflow into the well and the oil pumping rate. The expression for the motor speed presented in the paper can be used for the synthesis of a control system for the frequencyregulated electric drive of the jack pump, which will adjust the operation of the sucker-rod oil pumping unit to different flow rate values.

\section{References}

[1] Shageev, A.F., Timusheva, A.M., Shageeva, L.N., Grishkin, A.S. Automated monitoring of processing wells - the first stage of intelligent control systems. Oil Economy, 2000, No. 11, pp. 48-49. (in Russian)

[2] Barsky, V.A., Kurdyumov, D.S. Using automated electric drive in the control station of a sucker rod pumping unit. Problems of Automated Electric Drive. Theory and Practice. NTU KhPI Journal, 2003, No. 10, vol. 1, 284 p. (in Russian)

[3] Rossini, W.M. Alvarenga, B., Chabu, I.E., da Cruz, J.J., Cardoso, J.R. Sales R.M. New concept for lifting in onshore oil wells. IEEE Transactions on Industry Applications, vol. 44, no. 4, pp. 951-961, July-Aug. 2008. https://doi.org/10.1109/TIA.2008.926309

[4] Pozdeev, D.A., Kudryavtsev, S.V. ABB ALC800 intelligent station for jack pump control. Problems of Automated Electric Drive. Theory and Practice. NTU KhPI Journal, 2008, No. 30, pp. 265-268. (in Russian)

[5] V.V. Andreev, K.R. Urazakov, V.U. Dalimov, et al. Reference book of oil extraction. Nedra-Biznestsenter Publishers Ltd., Moscow, 2000, 374 p. (in Russian)

[6] Tagirova, K.F. Automation of control of oil extraction from stripper wells based on dynamic models. Extended abstract of ScD. theses, spec. 05.13.06, Ufa, 2008, 35 p. (in Russian)

[7] Terekhov, V.M., Osipov, O.I. Control system of electric drives: textbook for university students. Academia Publishers, Moscow, 2006, 304 p. (in Russian)

[8] Lozynskyi, O.Yu., Kaluzhnyi, B.S., Malyar, A.V. Study of the electric drive of a rod deep-well pumping unit. Technical Electrodynamics Journal, 2008, Thematic issue, vol.6, pp. 37-40. (in Ukrainian)

[9] Dorf, R.C., Bishop, R. Modern Control Systems Solution Manual, 11th ed. Prentice Hall: Upper Saddle River, NJ, USA, 2008,730 p.

[10] Feldbaum, A.A. Electrical automatic control system. ed. 2. Moscow: Nedra, 1957, 806 p. (in Russian)

[11] Malyar, A.V. Dynamics of the electric drive of a deep-well oil pumping unit. Technical Electrodynamics Journal, 2007, No. 2, pp. 50-54. (in Ukrainian)

\section{Методика вибору швидкості двигуна електроприводу верстата-гойдалки з урахуванням дебіту пласта}

\author{
Андрій Маляр, Богдан Калужний, Роман Квіт \\ Національний університет «Львівська політехніка», вул. С. Бандери, 12, м. Львів, 79013, Україна
}

\begin{abstract}
Анотація
На продуктивність нафтової штангової глибинопомпової установки впливає багато чинників, зокрема й режим роботи системи електроприводу верстата-гойдалки. Налаштування системи електроприводу вливають на енергетичні показники системи, тривалість міжремонтного періоду та кількість видобутої нафти. Таким чином, раціональна експлуатація нафтовидобувних установок $є$ важливим фактором, який впливає на вартість видобутої рідини. У статті запропоновано методику вибору швидкості привідного двигуна електроприводу верстата-гойдалки, яка дає змогу збалансувати продуктивність глибинної помпи та дебіт пласта. У якості похибки системи електроприводу вибрано різницю між подачею помпи та продуктивністю пласта. Методика базується на критерії мінімуму середньоквадратичної похибки і враховує періодично змінний характер моменту навантаження та моменту інерції електроприводу. На іï основі можна синтезувати систему керування електроприводом верстата-гойдалки, яка адаптуватиме роботу глибиннопомпової установки до різних значень допливу рідини у свердловину.
\end{abstract}

Ключові слова: глибиннопомпова установка; дебіт; система керування; середньоквадратична похибка. 